\title{
중증천식의 치료
}

울산대학교 의과대학 울산대병원 내과

이 태 훈

\section{Treatment of Severe Asthma}

\author{
Taehoon Lee \\ Department of Internal Medicine, Ulsan University Hospital, University of Ulsan College of Medicine, Ulsan, Korea
}

Severe asthma represents $3-10 \%$ of all cases of asthma, but accounts for $>60 \%$ of total asthma-related medical costs. Uncontrolled asthma symptoms and frequent asthma exacerbations associated with severe asthma have profound adverse effects on patients' quality of life. The concepts of difficult-to-treat asthma and severe asthma are different; severe asthma represents one kind of difficult-to-treat asthma. Misdiagnosis, nonadherence, and comorbidities may also be causes of difficult-to-treat asthma. This review discusses important principles in the treatment of difficult-to-treat asthma and severe asthma. (Korean J Med 2018;93:159-171)

Keywords: Severe asthma; Difficult-to-treat asthma

\section{서 론}

중증천식은 전체 천식의 3-10\%를 차지하지만[1,2], 전체 천식 관련 의료비용의 $60 \%$ 이상을 소모한다[3]. 의료비용의 대부분은 약제비인데, 중증천식 환자의 개인당 의료비용은 당뇨병이나, 뇌졸중, chronic obstructive pulmonary disease (COPD)보다 훨씬 높다[4]. 뿐만 아니라, 중증천식에 수반하 는 조절(control)되지 않는 천식 증상과 잦은 천식 악화는 환 자의 삶의 질을 매우 저하시키고, 중증천식의 치료를 위해 사용하는 약물(전신 스테로이드 등)에 의한 부작용 역시 환 자에게 큰 부담으로 작용한다[5].

\section{본 론}

\section{중증천식(severe asthma)과 난치천식(difficult-to-treat asthma)의 정의}

Global iNitiative for asthma (GINA) 지침에서 제시된 중증천 식의 정의는 2014년 european respiratory society (ERS)/american thoracic society (ATS) 지침에서의 정의와 거의 동일한데, $\mathrm{ERS} / \mathrm{ATS}$ 지침은 중증천식의 정의를 좀 더 구체적으로 기술 하고 있다[1]. 이에 대해서는 함께 게재된 "중증천식의 진단" 논문을 참고하기 바란다. 또한, 우리가 논하는 중증천식은 상당한 기간(수개월 이상) 동안의 조절제(controller) 치료를 시행한 후에 판단하기 때문에, 2007 national asthma education and prevention program 지침과 2008년 이전의 GINA 지침에

Correspondence to Taehoon Lee, M.D., Ph.D.

Department of Internal Medicine, Ulsan University Hospital, University of Ulsan College of Medicine, 877 Bangeojinsunhwan-doro, Dong-gu, Ulsan 44033, Korea

Tel: +82-52-250-7029, Fax: +82-52-250-7048, E-mail: ddol1996@hanmail.net 
- The Korean Journal of Medicine: Vol. 93, No. 2, 2018 -

서 소개되고 있는 조절제 유지 치료를 받지 않고 있는 천식 환자에서의 “중증 지속성 천식(severe persistent asthma)"과는 다르다[6].

그렇다면, 난치천식은 중증천식과 어떻게 다를까? 중증 천식은 반드시 천식이지만, 난치천식은 천식이 아닐 수도 있 다. 또한, 난치천식의 절반 정도는 최종적으로 중증천식으로 진단되지만, 일부는 천식이 아니었거나(잘못된 진단으로 천 식치료가 증상개선에 효과가 없었던 경우), 또 다른 일부는 순응도/흡입기 기술(adherence/inhaler technique)의 문제, 혹은 천식 동발 질환(comorbidities)의 문제, 급성 천식 악화 위험 인자/천식 증상 유발물질(exacerbation risk factors/asthma triggers)의 지속적인 노출 등에 의한 난치천식이었으나, 중증천 식에는 해당하지 않을 수 있다[1,7,8].

\section{난치천식의 치료 접근}

그림 1 의 윗부분에 난치천식의 치료접근에 대해서 요약하
였다. 위에 기술한 바와 같이 난치천식은 아래와 같은 단계 를 거쳐서, 정말 중증천식에 해당하는지를 확인하는 과정이 라 할 수 있다.

\section{Confirm: asthma diagnosis(정말 천식인가?)}

고강도의 천식 치료를 하고 있음에도, 환자의 증상(천식의 4대 증상인 기침[cough], 호흡 곤란[dyspnea], 천명[wheezing], 가슴 답답함[chest tightness] 중 한 가지 이상) 개선이 미비하 다면, 가장 먼저 확인할 것은 기존에 천식이 확진(confirm diagnosis)되었는지 확인하는 것이다. 비조절 천식의 $10-30 \%$ 가 결국은 non-asthmatic conditions로 진단되는 것으로 알려져 있다 $[1,9,10]$. 천식 확진은 천식의 증상이 있는 상태에서 가 변적 기도 폐쇄(variable airflow obstruction)가 폐기능 검사에 서 확인될 때 가능하다[7,11,12]. 조절제를 사용하는 상태에 서 천식 확진이 필요한 경우, "baseline spirometry forced expiratory volume in the first second (FEV1) $\rightarrow$ twice-daily peak expiratory flow rate (PEF) for 2 weeks (1st week: 기존 치료;

난치 천식 (difficult-to-treat asthma)의 치료접근

\begin{tabular}{|c|}
\hline Confirm: asthma diagnosis [정말 천식인가?] \\
\hline$\downarrow$ \\
\hline Check: adherence / inhaler technique [순응도 / 흡입기 기술은 적절한가?] \\
\hline$\downarrow$ \\
\hline Care: comorbidities [동반질환(들)의 조절로 천식 증상의 호전을 도모하자.] \\
\hline$\downarrow$ \\
\hline Control: exacerbation risk factors / asthma triggers [급성천식악화 위험인자와 천식증상유발물질을 제거하자.] \\
\hline 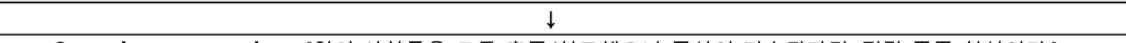 \\
\hline
\end{tabular}

\section{중증 천식 (severe asthma)의 치료접근}

\begin{tabular}{|c|c|}
\hline $\begin{array}{l}\text { Tests to identify } \\
\text { the treatable traits (phenotyps/endotypes) } \\
\text { for "specific severe asthma treatments" }\end{array}$ & $\begin{array}{l}\text { Optimizing controller treatment usually after a } \\
\text { course of oral GC or an i.m. of triamcinolone }\end{array}$ \\
\hline A course of oral GC or an inj. of triamcinolone & $\downarrow$ \\
\hline $\begin{array}{c}\text { Systemic GC responsiveness } \\
\text { Lower the burden of total inflammation }\end{array}$ & "Specific severe asthma treatments" \\
\hline $\begin{array}{l}\text { Blood eosinophil, FeNO, sputum eosinophil } \\
\text { Persistent type } 2 \text { inflammation despite high ICS }\end{array}$ & $\begin{array}{l}\text { Biologics for type } 2 \text { inflammation. } \\
\text { Low dose oral GC (5-10 mg/day PD equivalent) }\end{array}$ \\
\hline $\begin{array}{l}\text { Skin or serum sIgE detection test, seum total IgE } \\
\text { Allergic vs Non-allergic }\end{array}$ & $\frac{\text { Immunotherapy }}{\underline{\underline{\text { Omalizumab }}}}$ \\
\hline $\begin{array}{c}\text { Chest CT, DLCO, Lung Volume } \\
\text { (prn, sputum bacterial or AFB assay) } \\
\text { Bronchiectasis, NTM lung disease, COPD }\end{array}$ & $\begin{array}{c}\text { Azithromycin, } \\
\text { Pulmonary rehabilitation }\end{array}$ \\
\hline
\end{tabular}

Figure 1. Treatment approaches for difficult-to-treat asthma and severe asthma. 
2nd week: 기존 치료 + 경구스테로이드 단기요법 [prednisolone 30-60 mg/day 5-14days]) $\rightarrow$ follow-up spirometry (FEV1)"의 방법을 이용해볼 수 있다.

\section{Check: adherence/inhaler technique(순응도/흡입기} 기술은 적절한가?)

\section{순응도(adherence)}

낮은 순응도(poor adherence)란 환자가 약속한 치료를 하 지 않는 것이다. 천식 환자의 $50 \%$ 정도는 약제를 제대로 사 용하지 않는 시기가 있다[13]. 문제는 환자가 스스로의 치료 순응도를 정확하게 이야기하지 않을 때가 많고, 그들의 순응 도를 과대평가한다는 것이다[14]. 순응도의 확인을 위해 전 자흡입기모니터링이나 혈중농도 측정(치료 약물인 프레드 니솔론이나 코티솔), 약사의 조제기록 등의 방법이 소개되기 도 하나[5,10,15], 바쁜 임상 현장에서 이용하기는 쉽지 않다. 환자와 눈을 마주치고, 환자의 어려움을 십분 이해함을 표시 하는 공감적 질문(empathic question)을 통해 환자가 순응도 를 정확히 밝히도록 유도해야 한다[7,12]. 약제를 추가한 후 일정기간(3-6개월) 약제 순응도가 좋았음에도 불구하고 증상 이나 폐기능 개선이 없다면, 추가한 약제를 중단하는 것을 고려해야 한다[5].

환자가 약제 사용을 게을리하였다고 고백하면, 의사는 비 난하지 않는 태도(non-judgemental manner)로 환자 및 환자 보호자와 토론하여 비순응의 원인을 반드시 확인해야 한다. 이러한 경우 많은 환자로부터 의도적인 비순응(intentional poor adherence)을 확인할 수 있는데, 가장 많은 경우가 “(증 상이 없어지면) 치료가 필요 없다는 인식”과 “부작용에 대한 걱정"이다. 환자 스스로가 질환 및 치료의 효과를 이해하게 되면 치료 순응도는 매우 증가한다[7]. 환자의 질환 인식을 개선시킬 수 있는 설명의 예는 다음과 같다: “천식은 당뇨병 이나 고혈압과 같은 만성 질환입니다.”, “지금 사용 중인 흡 입제는 예방약(조절제)입니다. $\mathrm{OOO}$ 님의 천식 증상이 나타 나지 않게 해주고, 감기에 걸리더라도 심하게 나빠지지 않게 예방시켜줍니다. 만약 당신 이 약(조절)을 중단하면, 증상은 반드시 다시 나타납니다.”, “흡입제의 부작용은 매우 드뭅니 다. 만약 부작용이 생겨도 해결할 방법(약 변경 or device 변 경)이 많으므로, 언제든지 불편한 증상이 있으면 저희에게 알려주세요".

\section{흡입기 기술(inhaler technique)}

천식 치료의 가장 중심적인 약물은 흡입약물이므로, 환자 의 흡기력/인지 기능/동반 질환 등을 종합하여 흡입 치료의 방법(흡입기 종류)을 결정해야 한다. 예를 들어 고령 (인지기 능 저하가 있는 경우)의 관절염을 않고 있는 환자에게는 pressurized metered dose inhaler (pMDI) (+/-spacer)/dry powder inhaler (DPI)보다 네뷸라이져가 적합하다[16]. pMDI (+/-spacer)/DPI를 사용하기로 결정한 경우, 적절한 교육을 통해 흡입기 기술을 습득하도록 해야 한다. 또한, 처음 교육 후 4-6주 이내에는 환자의 천식이 잘 조절되고 있더라도, 한 번 더 흡입기 기술 을 점검하고, 이후 주기적인 점검이 필요하다. 만약, 천식이 조절되지 않는 상태로 환자가 방문한 경우에는, 좀 더 세밀 한 흡입기 기술 점검이 필요하다. 이때는 모형 흡입 기구 (placebo inhaler)를 가지고 직접 환자에게 시연하도록 지시한 후, 잘못된 단계를 확인한다. 다음으로 의사가 직접 모형을 이용하여 환자에게 흡입기를 제대로 사용하는 방법을 보여 준 후, 문제 있는 단계를 중심으로 사용 방법을 2-3번 다시 확인해 주는 것이 필요하다[7,17].

Care: comorbidities(동반 질환 조절로 천식 증상의 호전 을 도모하자)

비염 및 비부비동염, 위식도 역류 질환, 불안장애, 심장 질 환, 비만, 폐쇄성 수면 무호흡증 등을 포함한 천식 동반 질환 들은 천식 조절을 악화시키거나 증상의 원인이 될 수 있다 $[1,5,7,11,12]$. 경우에 따라서는 가변적 기도폐쇄가 확인된 상 황에서도(천식이 확진된 상황), 동반 질환을 치료한 후 환자 의 모든 증상이 사라지는 경우도 있다 (불안장애, 심장 질 환). 따라서, 비조절 천식 환자에서 동반 질환이 의심/확인되 면 적절한 협진과 다학제적 평가/치료를 신속히 시행해야 한 다[5]. 하지만 동반 질환의 조절이 어려운 경우도 많기 때문 에(비만, 비부비동염), 동반 질환을 치료하는 것이 중증천식 호전 여부에 미치는 영향에 대해서는 연구가 좀 더 필요해 보인다[11]. 몇 가지 중요한 천식 동반 질환들을 기존 연구와 필자의 경험을 바탕으로 아래와 같이 정리해보았다.

\section{비염(비부비동염)}

천식의 가장 흔한 동반 질환인 비염(비부비동염)은 천식 환자의 $90 \%$ 이상에서 나타난다[18]. 대개 비염은 천식보다 선행하는데 비염 환자의 $30 \%$ 정도에서 결국 천식이 발생한 다[12] (참고로 비염과 천식의 유병률은 각각 전 인구의 
$10-20 \%, 5-10 \%$ 로 알려져 있음). 특히, 중증 지속성 비염 (severe persistent rhinitis) 환자에서 천식이 많이 발생한다 [18]. 비부비동염은 천식 악화의 위험 인자이고[19], 비부비 동염의 치료는 천식 증상을 개선시킨다[20,21]. 비염(비부비 동염)은 전형적인 알레르기 비염 증상(맑은 콧물[전비루], 코 막힘, 재채기, 눈가려움) 없이, 비전형적 증상 (후비루, 목이 물감, 기침, 객담)만 나타나기도 한다(비알레르기 비염) [22]. 하지만, 알레르기 비염/비알레르기 비염 모두 치료의 핵심은 비강내 스테로이드(intranasal steroid, INS)이므로, 비염(비부 비동염)을 호소하는 천식 환자에게 기본적으로 INS를 처방 하고, 알레르기비염의 가능성이 높아 보이면 2세대 항히스 타민, 비알레르기 비염 가능성이 높으면 1세대 항히스타민 을 사용해볼 수 있다. 심한 비염 증상이 있을 때 생리식염수 코세척이나 단기간의 고용량 경구스테로이드, 화농성 비부 비동염이 발생한 경우 항생제를 사용하는 것이 도움이 된다. 더 자세한 비염의 치료는 최근 나온 가이드라인을 참고하기 바란다[23].

\section{위식도 역류 질환}

위식도 역류 질환(gastroesophageal reflux disease, GERD)은 자주(매일) 발생하는 가슴쓰림, 신물, 음식물 역류, 상복부 쓰림 등의 증상을 일으키는 질환으로 식도괄략근의 기능저 하로 인해 발생한다. 천식 환자에서 일반인보다 3 배 많은 $\mathrm{GERD}$ 빈도를 보인다고 알려져 있다[11]. 천식 환자에서 $\mathrm{GERD}$ 의 증상이 동반된 경우에는 $\mathrm{GERD}$ 의 치료(proton pump inhibitor, PPI)가 천식 증상/악화 감소에 도움이 되나, GERD 증상이 없는 경우에는 천식 outcome에 영향을 끼치지 않는 것으로 알려져 있다[24,25]. 따라서 비조절/중증천식에서 $\mathrm{GERD}$ 증상이 없을 때 천식 증상 개선이나 악화 예방을 목적 으로 PPI를 사용할 필요는 없다[7].

$\mathrm{GERD}$ 는 만성 기침의 원인이기도 하다. GERD로 인한 만 성 기침의 전형적인 임상 양상은 만성 기침과 $\mathrm{GERD}$ 증상이 함께 발생하는 것이나, 기침이 유일한 증상인 경우도 있다 (silent GERD) [26]. 특히, 기침이 주 증상인 비조절 천식에서 폐기능(FEV1)이 이전에 비해 나쁘지 않다면, 비부비동염 연 관 upper airway cough syndrome (UACS)이나 GERD를 의심 하여 경험적으로 두 질환에 대한 순차적인 치료를 시행하는 것은 매우 합리적이라고 할 수 있다[11].
비만

천식은 비만한 사람에게 더 흔하다[7]. 비만한 천식 환자는 천식 증상과 악화가 더 심하고, ICS의 치료 반응이 일반인에 비해 떨어지는 것으로 알려져 있다[7]. 5-10\%의 체중감소만으 로도 천식 조절과 삶의 질이 나아지므로[27], 비조절 천식 환 자가 비만하다면, 적극적인 체중감소를 권고해야 한다.

\section{정신과적 질환: 불안장애/과환기증후군/공황장애, 우울증}

불안장애(과환기증후군, 공황장애)와 우울증은 대표적인 천식 연관 정신 질환이다. 우울증은 일정 기간 이상 지속되는 우울한 기분 혹은 즐거움의 상실로, 특히 노인 천식 환자에게 잘 동반된다. 우울증은 잘 알려진 급성 악화의 위험 인자이고, 우울증의 관리를 잘 하면 천식도 더 잘 조절되는 것으로 알려 져 있다[7,11]. 불안장애는 천식에 병발하기보다 감별해야 할 필요가 더 높은 질환으로, 주로 스트레스에 민감한 젊은(10-40 대) 여자에서 발생한다. 불안장애는 초조하고 두려운 느낌과 함께 빈맥, 발한 등의 자율신경항진 증상을 보이는데, 심해지 면 과호흡증후군(심한 불안으로 인한 빠르고 깊은 호흡의 반 복)이나 공황장애(극심한 불안으로 인해 죽을 것 같은 느낌이 드는 것)로 나타난다[28]. 불안장애 역시 천식의 동반 질환으 로 발생할 수 있다. 경우에 따라서는 천식약물(베타항진제)이 환자에게 불안을 유도하기도 하는데, 이 경우 환자의 불안감 이 약물 치료 전부터 있었는지 확인해야 하고 베타항진제를 제외한 천식 약물을 사용하는 것이 요망된다.

환자의 증상이 천식만으로 설명되지 않는 것 같고, 특히 주관적 호흡곤란의 호소는 심하나 주로 안정시 호흡곤란을 운동시 호흡곤란보다 심하게 호소하고(일상 업무는 잘 하나 간헐적으로 혼자 쉬고 있을 때 호흡곤란 발생), 검사(FEV1) 상 정상이고 호흡곤란 외의 천식 증상(기침, 천명)이 관찰되 지 않거나 최근에 심한 스트레스를 경험하였던 경우 우울증 이나 불안장애의 동반 혹은 감별을 고려해야 한다[29]. 우울 증의 경우 한숨 쉬면서 탄식하는 호흡양상을 보이는데 비해, 불안장애 때는 흡기가 덜 이루어진 느낌을 호소하면서 반복 적으로 심호흡을 하는 모습을 보인다.

\section{성대기능부전}

성대기능부전(vocal cord dysfunction, $\mathrm{VCD}$ )은 후두과민증 (laryngeal hyperresponsiveness)이 있는 사람에서 스트레스/불 안, 후비루, GERD, 운동 및 비특이적 기도자극물질 등에 의 해 발생하는 갑작스런 성대의 기능적 폐쇄를 말한다[30]. 주 
로 젊은 여성에서 발생하는데, 천식에 병발하기도 하고, 천 식과 상관없이 발생하기도 한다. 증상이 완전히 소실되는 특 성으로 말미암아 천식 혹은 후두혈관부종으로 오인되어, 환 자에게 불필요한 천식 치료나 전신 스테로이드 치료를 받게 하기도 한다(기관지확장제나 스테로이드는 $\mathrm{VCD}$ 에 전혀 효 과 없음) [30]. 성대폐쇄가 발생하면, 호흡곤란, 쉰 목소리 (dysphonia)와 함께 흡기성 협착음(inspiratory stridor)이 목 주 위에서 들리게 된다. 증상이 있을 때 flow-volume curve에서 inspiratory flattening과 후두경 검사에서 성대의 앞부분 내전 (adduction)과 함께 뒷부분의 다이아몬드모양 chinking 소견 이 보이면 확진할 수 있으나, 확인하기는 쉽지 않아 대부분 은 임상적 추정 진단을 한다[30]. 목 이물감과 기침도 동반할 수 있다. 대부분은 증상 시작 5-10분 이내에 자연 소실되는 데, 물 마시기, 책 읽기, 심호흡, 발살바법, 헐떡거리면서 숨 쉬기(panting) 등의 성대에 관심을 두지 않는 주의산만 (distraction) 활동이 성대폐쇄의 종료에 도움이 된다[31]. 간 혹, 심한 증상으로 응급실에 내원하여 기관 삽관을 시행한 보고가 있으나, 본질적으로는 자연 호전되는 질환이다. 따라 서, 응급상황에서는 환자를 안심시키고(reassurance), 헐떡꺼 리면서 숨을 쉬도록 유도(panting respiration)하면 대부분 호 전된다[30]. 간혹, 심한 환자의 경우 호전될 때까지 CPAP를 적용해볼 수 있다[32,33]. 급성기 증상이 없어진 환자는 음성 치료(speech therapy)를 시행하여 마인드콘트롤 및 성대폐쇄 를 종료할 수 있는 호흡법을 배우도록 해야 한다. 또한 대부 분의 환자가 스트레스/불안장애를 가지고 있으므로 이에 대 한 정신과적 치료가 필요하다[30].
Control: exacerbation risk factors/asthma triggers (급 성 천식 악화 위험 인자와 천식 증상 유발물질을 제거하자)

\section{급성 천식 악화 위험 인자(exacerbation risk factors)}

표 1은 급성 천식 악화의 위험 인자이다[7,11]. 천식으로 치료 중인 환자에 대해 의료진은 1) 평가(assess), 2) 치료 조 정(adjust treatment), 3) 반응 확인(review response)의 과정을 정기적으로(병원에 방문할 때마다) 확인해야 한다(Fig. 2) [7]. 특히 비조절/난치성 천식 환자에서는 혹시 놓치고 있는 급성 악화 위험 인자가 있는지 면밀한 “평가(assess)”와 “치 료 조정(adjust treatment)”이 필요하다. 예를 들어, 혈액/객담 호산구나 호기 산화질소(high FENO)를 확인하여 그 수치가 정상보다 높다면, 적극적으로 조절제(ICS)를 증량해야 한다. 폐기능이 낮을 때에는 비록 증상이 적더라도(악화는 증가하 므로) 적극적으로 조절제를 증량/추가해야 한다. 또한, 급성 악화의 위험 인자가 없어지지 않은 상황에서는 치료단계내 림(step down treatment)은 신중해야 하고, 조절제(ICS)를 완 전히 중단해서는 안 된다.

\section{천식 증상 유발물질(asthma triggers)}

표 2는 천식 증상 유발물질이다[7,34]. 비조절/난치성 천식 환자에서는 좀 더 면밀한 유발물질 확인의 과정이 필요하다. 유발물질이 의심되는 경우, 증상과 의심되는 물질 사이에 상 관관계가 있는지 확인하기 위해 노출일기(노출/활동/환경, 증 상/PEF)를 쓰는 것이 도움이 된다. 알레르기물질(allergen, allergic antigen)은 특정 알레르기성 천식에서만 증상을 유발한다. 이에 비해 비알레르기성 기도자극물질의 경우 모든 천식 환 자(알레르기성 및 비알레르기성 천식)에게 증상을 유발시킬

\section{Table 1. Asthma exacerbation risk factors}

\begin{tabular}{|c|c|}
\hline Correctable risk factors & Uncorrectable risk factors \\
\hline 1. Obesity / Pregnancy / Smoking & 1. Severe asthma exacerbation within 1 year \\
\hline 2. Increased blood / sputum eosinophils, high FENO & 2. Ever intubated or in intensive care unit for asthma \\
\hline $\begin{array}{l}\text { 3. Uncontrolled asthma symptoms; Poor lung function (FEV1 } \\
<60 \% \text { predicted) }\end{array}$ & \\
\hline $\begin{array}{l}\text { 4. Inadequate ICS: not prescribed ICS; poor adherence; incorrect } \\
\text { inhaler technique }\end{array}$ & \\
\hline $\begin{array}{l}\text { 6. Persistence of exposure to asthma triggers (occupational ex- } \\
\text { posure substances, allergens, non-allergic airway stimulants) }\end{array}$ & \\
\hline $\begin{array}{l}\text { 7. Uncontrolled comorbidities: sinusitis, mental illness (depression), } \\
\text { heart disease, obesity }\end{array}$ & \\
\hline
\end{tabular}

FENO, fractional exhaled nitric oxide; FEV, forced expiratory volume in the first second; ICS, inhaled corticosteroid. 


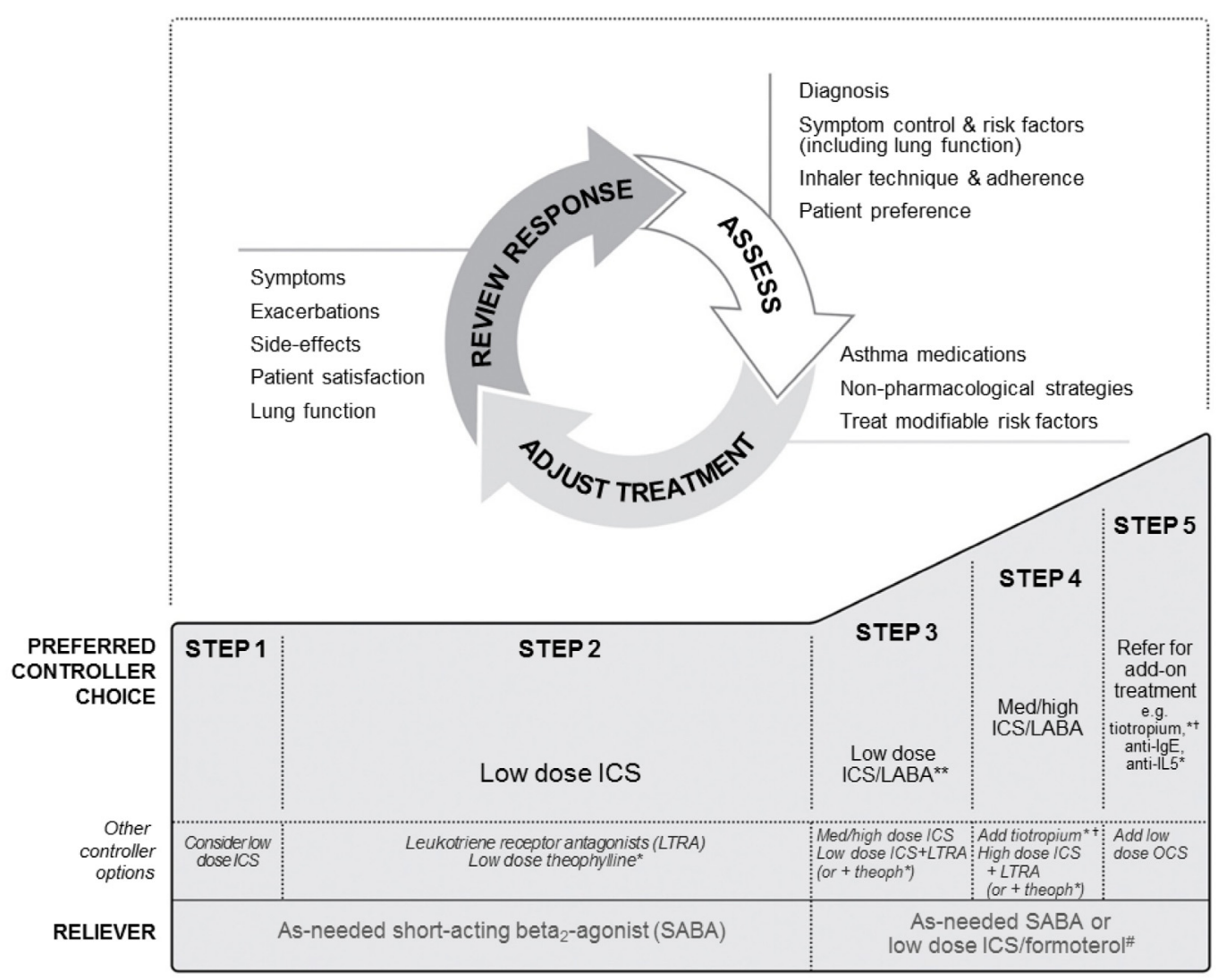

Figure 2. Global initiative for asthma (GINA) treatments steps (from GINA 2017).

\section{Table 2. Asthma triggers}

1. Allergens (symptoms only in certain asthmatics [allergen-specific asthma])

- House dust mite, cockroach, dog / cat, pollen, mold

2. Non-allergic airway stimulants (symptoms in most asthmatics [allergic or non-allergic asthma])

- Smoke (cigarette smoke), indoor air pollution (VOCs / secondhand smoke / food cooking smoke / gas oven range), outdoor air pollution (DEG / particulate matter / perfume)

* VOCs (volatile organic compounds): hydrocarbon compounds (benzene, formaldehyde, toluene, xylene, ethylene, styrene, acetaldehyde) leaking from wallpaper / floor plate / furniture of new house

* DEG (diesel exhaust gas): nitrogen dioxide / sulfur dioxide and particulate matter from diesel engines and factory soot

3. Strenuous exercise (symptoms in most asthmatics [allergic or non-allergic asthma])

* After the asthma have been controlled, all exercises are possible (aerobic exercise has substantial health benefits and may lessen sensitivity to asthma triggers)

4. Cold (flu) / pneumonia (symptoms in most asthmatics [allergic or non-allergic asthma])

* Vaccination against influenza and pneumonia is necessary.

5. Drugs (aspirin \& NSAIDs, cardiovascular drugs [ACEi / ARB]), food / food additives (sulfite), occupational exposure substances (symptoms only in certain asthmatics [drug hypersensitive/ food hypersensitive/ occupational asthma])

* Beta-blockers cause symptoms in most asthmatics (beta-1-selective blockers should be used)

NSAID, nonsteroidal anti-inflammatory drugs; ACEi, angiotensin-converting enzyme inhibitor; ARB, angiotensin receptor blockers.

수 있다. 천식 증상 유발물질을 제거하거나 회피하는 것은

천식의 조절에 있어서 효과는 확실하다[7,34]. 하지만 천식의

조절에 이르게 할 만큼 충분히 유발물질 노출을 줄이는 방법
에 대해서는 아직 논란이 많고, 유발물질을 완전히 제거하는 것은 사실상 불가능하다[34]. 따라서, 유발물질의 노출이 있 더라도 천식 증상이 발생하지 않게 하는 약물 치료(특히, 흡 
- Taehoon Lee. Treatment of severe asthma -

입약물 조절제)가 유발물질의 회피(환경관리)보다 훨씬 더 중요하다[7].

\section{알레르기물질(allergen, allergic antigen)}

흔한 알레르기물질은 집먼지 진드기, 애완동물의 털, 바퀴 벌레, 곰팡이, 꽃가루 등이 있다. 한 가지 환경관리 방법 (single intervention: allergen impermeable bed cover)으로는 임 상적 호전을 기대할 수 있을 정도의 충분히 알레르기물질을 감소시키지 못하는 것으로 알려져 있으나, 포괄적인 환경관 리(multi-component intervention: allergen impermeable bed cover+HEPA filtered vacuum cleaner+HEPA filtered air cleaner+No pets+No damp area)로 실내알레르기항원에 대한 노출을 줄이 면 천식 관련 이환율을 감소시키는 효과가 있었다[35]. 하지 만, 모든 연구 결과가 일관성 있게 나오지 않았고[36], 환경 관리에 드는 비용이 많아 비용 효과적이지 않은 면이 있으므 로, 알레르기물질 회피(allergen avoidance)는 천식관리의 일 반적인 전략으로 권장되지 않고 있다(GINA 2017 Appendix, Chapter 6, Non-pharmacological therapies and strategies) [7]. 하 지만 현실적으로 비조절/난치성 천식 환자에서는 증상조절 과 악화예방을 위한 모든 노력을 경주해야 하므로, 환자가 경제적으로 여유가 있다면 포괄적인 환경관리(알레르기 물 질 회피)를 추천하는 것이 합리적이라고 판단된다.

비알레르기성 기도자극물질

비알레르기성 기도자극물질에는 실내공기오염 $(\mathrm{VOCs} /$ 간 접흡연/음식물조리연기/가스레인지), 실외공기오염( $\mathrm{DEG} /$ 미 세먼지/향수), 기후/온도 변화(차고 건조한 공기) 등이 있다. 천식이 잘 조절되고 있는 환자에서 천식에 좋지 않은 환경조 건을 반드시 피할 필요는 없다. 그러나 천식 조절이 안 되는 환자는 기도자극물질이 많은 상태에서는 신체 활동을 피하 는 것이 바람직하다(GINA2017 Appendix, Chapter 6, Nonpharmacological therapies and strategies) [7]. 차고 건조한 곳에 있을 때 두꺼운 마스크를 사용하면 공기를 습하고 따뜻하게 하는데 도움이 된다[37].

약물, 식품/식품첨가물, 직업성 노출물질

Aspinin \& NSAIDs: 전체 천식의 7\%, 중증천식의 $15 \%$ 는 aspirin \& NSAIDs에 의해 천식증상이 나빠질 수 있는 아스피린 악화 기도 질환(aspirin-exacerbated respiratory disease, AERD) 에 해당한다[7]. 아스피린 악화 기도 질환(AERD)은 천식, 만
성 용종성 부비동염이 있는 환자에서 아스피린 과민성 (aspirin or NSAIDs에 노출되었을 때 bronchospasm과 nasal congestion이 발생)이 있을 때 진단할 수 있다. 과거에는 아스 피린 유발 천식(aspirin-induced asthma) 혹은 아스피린 과민 성 천식(aspirin-sensitive asthma)이라고 불렀으나, 아스피린 과민성은 $\mathrm{AERD}$ 의 한 가지 특성에 불과하고(물론 중요한 특 성이지만), 기저에 아스피린과 무관하게 진행하는 천식과 만 성 용종성 부비동염이 있으므로, 최근에는 $\mathrm{AERD}$ 로 부르고 있다[38,39]. $\mathrm{AERD}$ 의 진단은 천식 환자에서 아스피린과민성 의 병력을 확인함으로써 가능하나, 병력이 모호한 경우(여러 가지 약물이 들어간 후 반응이 생겼거나, 일관성 있게 반응 이 생기지 않은 경우)에는 oral aspirin challenge test 혹은 bronchial aspirin (lysine aspirin) challenge test를 시행해볼 수 있다. $\mathrm{AERD}$ 로 확인되면, 진통소염제를 사용할 때 교차반응 이 없는 selective COX (cyclooxygenase)-2 inhibitor나 acetaminophen (고용량[1회용량이 $1,000 \mathrm{mg}$ 이상]에서는 교차반 응 가능)을 사용해야 한다[40,41]. 우리나라에서는 잘 시행하 지 않지만, aspirin desensitization도 고려해볼 수 있다[39].

ACEi/ARB: angiotensin-converting enzyme inhibitor (ACEi) 는 천식의 악화 없이, 기침을 유발시킬 수 있다(ACEi 사용자 의 20\%) [42]. Angiotensin receptor blocker (ARB)는 드물게 기 침을 일으킬 수 있다는 보고가 있으나[43], 대체적으로 기침 을 일으키지 않는다고 여기고 있다[42]. ACEi에 의해 발생한 기침은 대부분 중단하면 1-4주 이내에 호전된다[42]. 비조절/ 난치성 천식 환자가 기침과 함께 $\mathrm{ACEi}$ 나 $\mathrm{ARB}$ 를 사용 중이 라면 $\mathrm{ACEi} \rightarrow \mathrm{ARB}, \mathrm{ARB} \rightarrow$ angiotensin 무관약물로 변경하 는 것은 합리적으로 보이나, 1 달 이내 기침의 호전이 없다면 $\mathrm{ACEi}$ 나 $\mathrm{ARB}$ 와는 무관하다고 판단할 수 있으므로, 환자 상 태에 따라 $\mathrm{ACEi} / \mathrm{ARB}$ 의 재사용을 고려할 수 있겠다.

베타차단제: 베타차단제는 대부분의 천식 환자에게 bronchospasm을 유도하고[7], 이것은 소량(topical beta-blocker eye drop)으로도 발생할 수 있다[44]. 베타차단제가 필요한 상황 에서는 베타 1 선택차단제를 사용해야 한다. 경우에 따라서는 베타1선택차단제 역시 bronchospasm을 유도하므로, 증상이 있는 난치성 천식 환자에서 대체약물이 있고, 베타차단제를 반드시 사용하지 않아도 된다면 중단하는 것이 합리적이다.

식품/식품첨가물(food/food additives): 천식의 악화 요소로 서 음식물 알레르기는 흔하지 않다[7]. 음식물 회피는 확실한 병력 혹은 경구유발시험으로 알레르기가 완전히 증명되기 전까지는 권고하지 않는다. 식품첨가물은 식품의 보존이나 
가공과정에서 들어가는 물질로 설파이트(sulfite, 아황산염), 타트라진(tatrazine, 식용색소 황색 제5호), 벤조산염(benzoate), 글루탐산나트륨(monosodium glutamate, MSG) 등이 bronchospasm을 일으킬 수 있다고 보고되었다. 하지만, 최근에는 설 파이트 외에는 bronchospasm 유발이 없다고 보고 있다[7,12] 설파이트는 와인/맥주, 말린 과일/건어물, 가공된 감자, 새우 와 같은 식품의 보존제 및 산화방지제로 이용하는데, 섭취 후 즉각형 과민반응(bronchospasm, urticaria)이 발생할 수 있 다[34]. 전체 천식 환자의 $5-10 \%$, 중증천식 환자의 $10-20 \%$ 에 서 설파이트 섭취에 의해 bronchospasm이 발생할 수 있는 것 으로 알려져 있다[45,46]. 진단은 명확한 병력 혹은 유발시험 을 통해 가능하다. 진단되면 식품의 첨가물로 설파이트 제제 (sulfur dioxide, sodium sulfite, sodium bisulfite, sodium metabisulfite, potassium bisulfite, potassium metabisulfite)가 포함된 것은 최대한 회피하도록 교육해야 한다[34].

직업성 노출물질: 작업연관천식(work-related asthma, WRA) 에는 직업성 천식(occupational asthma, $\mathrm{OA}$ )과 작업악화천식 (work-exacerbated asthma, WEA)이 있고, $\mathrm{OA}$ 는 추가적으로 sensitizer-induced OA와 irritant-induced OA로 나뉜다[47]. Irritant-induced $\mathrm{OA}$ 의 경우 고농도 가스(세정제/소독제[염소 가스, 암모니아, 빙초산, 글루타르알데히드 등])의 호흡기 노 출 24 시간 내에 천식증상이 발생한 병력을 보고 진단한다. Sensitizer-induced $\mathrm{OA}$ 는 작업장 사용물질(material safety data, $\mathrm{MSD}$ )을 검토하고 work-related change를 serial PEF (or FEV1) 를 통해 확인하거나, 직접적인 기관지유발시험을 통해 진단 한다[48]. Sensitizer-induced $\mathrm{OA}$ 의 경우 직종의 변경이 반드 시 필요하나, irritant-induced $\mathrm{OA}$ 와 WEA는 적절한 노출관리 (작업장 환경관리, 마스크)가 이루어진다면 직종유지가 가능 하다[49]. 비조절/난치성 천식 환자에서 직업(직종) 및 작업 연관성(work-relatedness)의 확인은 반드시 필요하고, 직종변 경과 노출관리에 대한 조언/교육을 해야 한다.

\section{중증천식(severe asthma)의 치료 접근}

비조절/난치천식 환자에 대해 다른 질환 배제(diagnosis other than asthma)와 교정 가능 인자(potentially modifiable factors: adherence/inhaler technique, comorbidities, exacerbation risk factors/ asthma triggers)에 대한 조치를 적극적으로 시행하였음에 도 천식 증상이 지속될 때 비로소 중증천식 진단이 부여될 수 있다(Fig. 1). 중증천식으로 확인(concede)되면, 조절제 치료를 극대화(최적화)함과 동시에 treatable traits (for phenotype or en- dotype)를 확인하기 위한 검사를 시행해야 한다[50]. 조절제 치 료를 극대화(최적화)하였음에도 증상이 지속되는 천식 환자 에게는 확인된 treatable traits (for phenotype or endotype) 결과 를 바탕으로 specific severe asthma treatments의 시행을 고려하 여야 한다. 이 경우 의료비용의 증가(biologics 등)와 치료의 부 작용 발생(전신스테로이드 유지 치료에 의한 골다공증 등)이 가능하므로, 환자/보호자와 비용-효과/위험-이익에 대한 충분 한 협의를 한 후 치료 여부를 결정해야 한다(Fig. 1). 또한 많은 중증천식 환자에서 완벽한 증상조절은 불가능한 경우가 많으 므로, 높은 정도의 증상조절보다는 악화로 인한 응급실 방문 을 줄이는 것을 목표로 하는 것이 더 바람직할 수 있다[11]. 대부분의 천식지침은 중증천식으로 확인될 경우 경험 많은 천 식전문가에게 환자를 의뢰할 것을 권고한다[1,5,7].

Optimizing controller treatment usually after a course of oral glucocorticoid (GC) or an i.m. of triamcinolone

중증천식으로 확인되면, treatable traits (phenotyps/endotypes)의 확인을 위한 검사를 시행함과 동시에, 조절제 (controller) 치료를 최적화(optimization)해야 한다. 현재 비조 절 상태인 경우, 조절제 치료의 최적화와 함께 단기간의 고 용량 전신스테로이드 치료를 고려해볼 수 있다.

\section{조절제 치료의 최적화(optimizing controller treatment)}

중증천식도 일반 천식과 마찬가지로 조절을 목표로 단계 별 약물 치료(stepwise treatment)를 시행한다(Fig. 2) [7]. GINA step 4까지의 약물(high ICS/LABA, tiotropium, theophylline, LTRA)을 모두 다 사용하고 있는 상태에서도 환자의 천식이 비조절 상태라면(동시에, 다른 질환 배제되고, 교정가능인자 에 대한 모든 조치가 이루어진 경우) ICS 용량을 very high dose (high dose의 2 배 정도)까지 올려볼 수 있다(very high dose: fluticasone, 1,000-2,000 $\mu \mathrm{g}$; budesonide, 1,600-3,200 $\mu \mathrm{g}$ ) [7,51,52]. Smaller particle ICS (beclomethasone, budesonide)를 기존 ICS에 추가하는 방법을 써볼 수도 있다[51]. ICS 증량(as very high dose)은 천식 조절에 도움이 확실히 되나, 부작용(oral candidiasis, osteoporosis) 발생이 증가하므로, 이에 대해 모니터링 이 필요하다[7,53-56].

단기간의 고용량 전신스테로이드 치료(a course of oral GC or an i.m of triamcinolone)

중증천식 환자가 현재 비조절 상태인 경우 type 2 inflammation을 확인하는 검사(blood eosinophil, FeNO, sputum 
eosinophil)를 시행한 후, 단기간의 고용량 전신스테로이드 치료를 고려해볼 수 있다(prednisolone $40 \mathrm{mg}$ [30-60 mg]/day for upto 2 weeks; triamcinolone $80 \mathrm{mg}$ [40-120 mg] IM once) [57-60]. 단기간의 고용량 전신스테로이드는 염증을 억제하 여, 스테로이드 반응성을 유지하는 데 도움이 되는데, 그 이 유는 염증(inflammation)은 그 자체로 스테로이드 반응성을 약화시키기 때문이다(염증이 있으면 proinflammatory transcription factor인 activation protein (AP)-1을 활성화되고, $\mathrm{IL} 2 / \mathrm{IL} 4$ 가 증가함). 단기간의 고용량 전신스테로이드 치료는 환자의 장기적인 흡입스테로이드가 효과를 유지할 정도로 기도 염증을 줄일 수 있다[61,62].

Tests to identify the treatable traits (phenotyps/ endotypes) \& Specific severe asthma treatments"

Persistent type 2 inflammation despite high ICS \& Systemic GC responsiveness

고강도 천식 치료(GINA step 4 treatment [high ICS/LABA] 이상의 천식 치료)를 시행함에도 불구하고, 환자의 천식이 중증천식일때, treatable traits (phenotyps/endotypes)의 확인을 위해서 blood eosinophil, FeNO, sputum eosinophil을 시행해야 한다[5]. Blood eosinophil $\geq 300 / \mathrm{ul}, \mathrm{FENO} \geq 20 \mathrm{ppb}$, or sputum eosinophil $\geq 2 \%$ 인 경우 "persistent type 2 inflammation despite high ICS"로 판단할 수 있다[5]. Type 2 inflammation을 확인 하는 검사 직후 고용량의 전신스테로이드를 일정기간 사용 한 후 증상과 폐기능의 개선이 있는지 확인해보는 것 역시 필요하다(systemic GC responsiveness) [57-60]. Type 2 inflammation과 고용량 전신스테로이드 반응은 현재 상용화된 생물학적 제제(biologics [omalizumab, anti-IL5])나 저용량 전 신스테로이드 유지 치료에 효과가 있을 가능성을 높이는 trait이다[63,64]. 이러한 trait를 가진 환자에서 비조절 혹은 악화 때문에 사용하는 OCS bursts(단기간의 고용량 전신스테 로이드 사용)가 너무 잦다면(2-3개월에 1번 이상) 저용량 전 신 스테로이드 유지 치료(5-10 mg/day)나 생물학적 제제의 사용을 심각하게 고려해야 한다[65]. 전신스테로이드는 비록 저용량이더라도 장기간 사용시 부작용(골다공증, 비만 [cushing], 당뇨병, 여드름, 감염 등)이 발생할 수 있으므로 충 분한 설명 후 치료를 시작해야 한다[7]. 특히 3개월 이상 전 신스테로이드(저용량이더라도) 사용이 예상되는 경우에는 골다공증 예방 치료(calcium \& vitamin D)를 반드시 해야 하 고, 골다공증에 대한 모니터링이 필요하다[7]. 만약 경제적으
로 여유가 있는 환자라면, 저용량 전신스테로이드 유지 치료 보다 생물학적 제제를 먼저 고려하는 것이 바람직하다(현재 시판중인 생물학적 제제는 부작용이 많지 않음). 생물학적 제제와 관련한 자세한 내용은 함께 게재된 "중증천식의 치 료(생물학적 제제)” 종설 논문을 참고하기 바란다.

\section{Allergy test (skin or senum sIgE detection test, senum total} IgE)

중증천식의 경우 경증천식에 비해 알레르기성 천식 (allergic asthma)이 드문 것으로 알려져 있다. 하지만 알레르 겐(알레르기물질 [allergen])에 대한 specific $\operatorname{IgE}(\mathrm{sIgE})$ 존재를 확인함으로서 환경관리(allergen avoidance)를 통한 천식 조절 에 도움을 줄 수 있으므로, allergy test의 시행을 통해 알레르 기성 천식의 가능성이 있는지 반드시 확인해야 한다[1,7].

또한 통년성 알레르겐(perennial allergen: dust mite, animal dander, cockcroach, or molds)에 대한 sIgE가 확인된 중증천식 의 경우 omalizumab을 사용할 수 있다(omalizumab의 적응증: 중증천식, sIgE to a perennial allergen, 6세 이상, serum total $\mathrm{IgE}$ 30-1500 IU/mL) [5]. Omalizumab 사용자 중 치료 반응(천 식증상의 호전)은 $60-70 \%$ 정도에서 늦어도 치료 개시 4 개월 내 에는 나타난다(responder of omalizumab) [1,66]. Omalizumab은 type 2 inflammation이 있을 때(persistent type 2 inflammation despite high ICS) 치료 반응이 좋은 것으로 알려져 있다[5].

뿐만 아니라, $\mathrm{sIgE}$ 의 확인을 통해 immunotherapy (subcutaneous immunotherapy [SCIT] or sublingual immunotherapy [SLIT])를 시도해볼 수 있다. 단, immunotherapy의 시작은 천식이 악화 가 아닌 상태에서 시작해야 하며, FEV1 $>70-80 \%$ 인 상태에 서 시행하는 것이 바람직하다[67,68].

\section{Chest CT, DLCO, Lung volume}

중증천식으로 확인되면, 흥부 computed tomography (CT) 를 시행하는 것이 바람직하다. 2014년 ERS/ATS 지침에서는 비특이적 증상(객담이 많은 경우, 폐기능의 빠른 저하, DLCO 감소, 아토피 없음)을 보일 때만 흥부 CT 시행을 권고 하나(의료비용과 부작용 때문에) [1], 우리나라는 CT 비용이 저렴하고, 최근에는 저선량 흥부 CT가 널리 이용되므로, 모 든 중증천식 환자에게 한번은 흥부 $\mathrm{CT}$ 를 시행하는 것이 합 리적이라고 판단된다. 일반적으로 천식 환자는 흥부 CT에서 미만성 기도벽 비후, 기도내강협착, 모자이크 폐 감쇄 등이 관찰될 수 있다[69,70]. 이러한 병변들 외에 기관지확장증이 
나 폐침윤(중심소엽성 결절)이 발견되면, 객담 세균/항산균 배양 검사 시행하고, 국소적인 기도벽 비후/폐쇄가 보이면 기관지내시경을 고려해야 한다. 흥부 CT를 통해 예상치 않 은 동반 질환(결핵/비결핵 항산균 폐질환, 폐기종, 기관지확 장증 등)이 발견되거나, 전혀 다른 진단(기도이물, 기도종양 등)이 이루어지기도 한다[71]. DLCO와 lung volume 측정 또 한 필요하다. 동반 질환 혹은 대체진단으로 $\mathrm{ILD}$ 나 $\mathrm{COPD}$ 가 가능하기 때문이다[1,7].

흥부 CT 및 DLCO와 lung volume 등의 검사를 통해, 환자 천식의 중증도에 $\mathrm{COPD}$ 가 상당한 영향을 끼친다고 판단되면 (asthma-COPD overlap [ACO]라면), azithomycin이나 pulmonary rehabilitation을 고려해 볼 만하다[5,72]. 만약, 흥부 CT에 서 다른 큰 이상 소견이 없이 미만성 기도벽 비후가 보이고 이것이 기도평활근 증식에 의한 기도 개형 때문으로 여겨지 면, bronchial thermoplasty를 고려해볼 수 있겠다[1]. 하지만 bronchial thermoplasty는 아직 정확한 반응군이 정의되지 않 았고, 이전 연구가 FEV1 $>60 \%$ 이상의 환자에서만 주로 시 행되었으며, 시술 도중의 천식 악화나 폐렴 발생 등의 부작 용 발생 보고가 있어서, $2014 \mathrm{ERS/ATS} \mathrm{지침에서} \mathrm{적극적} \mathrm{시}$ 행보다는 추가적인 연구 결과(폐기능 개선, 악화 감소에 대 한 장기효과)가 축적되기 전까지는 연구 목적으로만 시행하 도록 권고하고 있다[1].

\section{기타}

위의 사항 이외에 중증천식 환자에게 고려해야 할 사항으 로 1) 천식 교육(천식정보제공 및 지식함양) 및 천식행동지 침(자기관리훈련) 수립, 2) 예방접종(독감, 폐구균) 등이 있다 [7,12]. 천식에 있어서 폐구균의 예방접종은 독감만큼 강조되 지는 않으나(고령자나 소아 외) [7], 중증천식 환자에서는 접 종하는 것이 합리적이라고 판단된다.

Macrolide 항생제 유지 요법은 중증 COPD에서 악화예방 에 도움이 되는 약물이다[72]. 중증천식 환자에서도 비호산 구성 trait를 보이는 경우 macrolide 유지요법이 급성 악화의 빈도감소에 도움이 되었다[12]. 하지만 아직까지 대규모 연 구가 부족하고 연구 결과가 일관되지 않아 일반화하기에는 이른 실정이어서, 중증천식에서 악화예방이나 천식 조절 목 적으로 macrolide 유지 요법을 권고하지는 않는다[1,12]. 비타 민 D 또한 천식 조절에 도움이 된다는 보고가 일부 있으나, 대규모 연구가 부족하고 반대의 결과도 있어서 더 많은 연구 가 필요한 실정이다[7].

\section{결 론}

중증천식의 치료는 난치천식의 치료접근에서부터 시작한 다. 난치천식 환자에서 다른 질환을 배제하고, 교정 가능인 자에 대한 조치를 적극적으로 시행하였음에도 천식 증상이 지속될 때 비로써 중증천식 진단이 부여될 수 있다. 중증천 식으로 확인되면, 조절제 치료를 적정화함과 동시에 treatable traits가 있는지 조사가 필요하다. 조절제 치료를 극대화하였 음에도 증상이 지속되는 천식 환자에게는 확인된 treatable traits 결과를 바탕으로 specific severe asthma treatments의 시 행을 고려하여야 한다.

중심 단어: 중증천식; 난치천식

\section{REFERENCES}

1. Chung KF, Wenzel SE, Brozek JL, et al. International ERS/ATS guidelines on definition, evaluation and treatment of severe asthma. Eur Respir J 2014;43:343-373.

2. Hekking PP, Wener RR, Amelink M, Zwinderman AH, Bouvy ML, Bel EH. The prevalence of severe refractory asthma. J Allergy Clin Immunol 2015;135:896-902.

3. Sadatsafavi M, Lynd L, Marra C, et al. Direct health care costs associated with asthma in British Columbia. Can Respir J 2010;17:74-80.

4. O'Neill S, Sweeney J, Patterson CC, et al. The cost of treating severe refractory asthma in the UK: an economic analysis from the British thoracic society difficult asthma registry. Thorax 2015;70:376-378.

5. Israel E, Reddel HK. Severe and difficult-to-treat asthma in adults. N Engl J Med 2017;377:965-976.

6. National asthma education and prevention program: expert panel report III: guidelines for the diagnosis and management of asthma. 2007.

7. 2017 GINA Report, Global Strategy for Asthma Management and Prevention.

8. 2012 GINA Report, Global Strategy for Asthma Management and Prevention.

9. Aaron SD, Vandemheen KL, Boulet LP, et al. Overdiagnosis of asthma in obese and nonobese adults. CMAJ 2008; 179:1121-1131.

10. Robinson DS, Campbell DA, Durham SR, Pfeffer J, Barnes PJ, Chung KF. Systematic assessment of difficult-to-treat asthma. Eur Respir J 2003;22:478-483. 
11. The Korean Academy of Asthma, Allergy and Clinical Immunology. Korean Guideline for Asthma. Seoul: The Korean Academy of Asthma, Allergy and Clinical Immunology, 2015.

12. The Korean Academy of Asthma, Allergy and Clinical Immunology. Asthma Treatment Guideline. Seoul: The Korean Academy of Asthma, Allergy and Clinical Immunology, 2014.

13. Boulet LP, Vervloet D, Magar Y, Foster JM. Adherence: the goal to control asthma. Clin Chest Med 2012;33:405-417.

14. Bae YJ, Kim TB, Jee YK, et al. Severe asthma patients in Korea overestimate their adherence to inhaled corticosteroids. J Asthma 2009;46:591-595.

15. Gamble J, Stevenson M, McClean E, Heaney LG. The prevalence of nonadherence in difficult asthma. Am J Respir Crit Care Med 2009;180:817-822.

16. Chapman KR, Voshaar TH, Virchow JC. Inhaler choice in primary practice. Eur Respir Rev 2005;14:117-122.

17. Basheti IA, Reddel HK, Armour CL, Bosnic-Anticevich SZ. Improved asthma outcomes with a simple inhaler technique intervention by community pharmacists. J Allergy Clin Immunol 2007;119:1537-1538.

18. Bergeron C, Hamid Q. Relationship between asthma and rhinitis: epidemiologic, pathophysiologic, and therapeutic aspects. Allergy Asthma Clin Immunol 2005;1:81-87.

19. ten Brinke A, Sterk PJ, Masclee AA, et al. Risk factors of frequent exacerbations in difficult-to-treat asthma. Eur Respir J 2005;26:812-818.

20. Pauwels R. Influence of treatment on the nose and/or the lungs. Clin Exp Allergy 1998;28 Suppl 2:37-40.

21. Adams RJ, Fuhlbrigge AL, Finkelstein JA, Weiss ST. Intranasal steroids and the risk of emergency department visits for asthma. J Allergy Clin Immunol 2002;109:636642.

22. Koh YI. Diagnosis of allergic rhinitis. Korean J Med 2013;85:452-456.

23. The Korean Academy of Asthma, Allergy and Clinical Immunology. Guidelines for clinicians: allergic rhinitis. Seoul: Medrang Ltd., 2015.

24. Mastronarde JG, Anthonisen NR, Castro M, et al. Efficacy of esomeprazole for treatment of poorly controlled asthma. N Engl J Med 2009;360:1487-1499.

25. Chan WW, Chiou E, Obstein KL, Tignor AS, Whitlock TL. The efficacy of proton pump inhibitors for the treatment of asthma in adults: a meta-analysis. Arch Intern Med 2011;171:620-629.

26. Irwin RS. Chronic cough due to gastroesophageal reflux disease: ACCP evidence-based clinical practice guidelines. Chest 2006;129(1 Suppl):80S-94S.

27. Scott HA, Gibson PG, Garg ML, et al. Dietary restriction and exercise improve airway inflammation and clinical outcomes in overweight and obese asthma: a randomized trial. Clin Exp Allergy 2013;43:36-49.

28. Korean Neuropsychiatric Association. Neuropsychiatry. Seoul: Hanauihagsa, 1998.

29. Kim TH. Differential diagnosis and treatment of dyspnea Korean J Med 2009;76:425-430.

30. Dunn NM, Katial RK, Hoyte FCL. Vocal cord dysfunction: a review. Asthma Res Pract 2015;1:9.

31. Cohen SM. Diagnosis and Management of vocal cord dysfunction. J Nurse Pract 2010;6: 675-682.

32. Heiser JM, Kahn ML, Schmidt TA. Functional airway obstruction presenting as stridor: a case report and literature review. J Emerg Med 1990;8:285-289.

33. Goldman J, Muers M. Vocal cord dysfunction and wheezing. Thorax 1991;46:401-404.

34. The Korean Academy of Asthma, Allergy and Clinical Immunology. Asthma and allergic diseases. Seoul: Yeomungag, 2012.

35. Morgan WJ, Crain EF, Gruchalla RS, et al. Results of a home-based environmental intervention among urban children with asthma. N Engl J Med 2004;351:1068-1080.

36. Crocker DD, Kinyota S, Dumitru GG, et al. Effectiveness of home-based, multi-trigger, multicomponent interventions with an environmental focus for reducing asthma morbidity: a community guide systematic review. Am J Prev Med 2011;41(2 Suppl 1):S5-S32.

37. Beuther DA, Martin RJ. Efficacy of a heat exchanger mask in cold exercise-induced asthma. Chest 2006;129:1188 -1193 .

38. Berges-Gimeno MP, Simon RA, Stevenson DD. The natural history and clinical characteristics of aspirin-exacerbated respiratory disease. Ann Allergy Asthma Immunol 2002;89: 474-478.

39. Adkinson. Middleton's Allergy: Principles and Practice. In Hypersensitivity to Aspirin and Other Nonsteroidal Antiinflammatory Drugs. 8th ed. New York: Elsevier, 2014:1296-1309.

40. Stevenson DD. Aspirin and NSAID sensitivity. Immunol Allergy Clin North Am 2004;24:491-505, vii.

41. Kim YJ, Lim KH, Kim MY, et al. Cross-reactivity to acetaminophen and eelecoxib according to the type of nonsteroidal anti-inflammatory drug hypersensitivity. Allergy Asthma Immunol Res 2014;6:156-162.

42. Dicpinigaitis PV. Angiotensin-converting enzyme inhibitorinduced cough: ACCP evidence-based clinical practice guidelines. Chest 2006;129(1 Suppl):169S-173S.

43. Baker-Smith CM, Benjamin DK Jr, Califf RM, Murphy MD, Li JS, Smith PB. Cough in pediatric patients receiving angiotensin-converting enzyme inhibitor therapy or angiotensin receptor blocker therapy in randomized controlled 
trials. Clin Pharmacol Ther 2010;87:668-671.

44. Morales DR, Dreischulte T, Lipworth BJ, Donnan PT, Jackson C, Guthrie B. Respiratory effect of beta-blocker eye drops in asthma: population-based study and meta-analysis of clinical trials. Br J Clin Pharmacol 2016;82:814-822.

45. Yoon HJ, Jee YK, Kim YY, Cho SH, Min KU. The prevalence of sensitivity to sulfiting agents in patients with bronchial asthma. Allergy 1994;14:311-317.

46. Park HS, Cho YH, Kim SS, et al. Pervalence of sensiticity to aspirin (ASA) and food additives in subjects diagnosed as having intrinsic asthma. J Asthma Allergy Clin Immunol 1998;18:662-671.

47. Tarlo SM, Balmes J, Balkissoon R, et al. Diagnosis and management of work-related asthma: American College Of Chest Physicians Consensus Statement. Chest 2008;134(3 Suppl):1S-41S.

48. The national institute for occupational safety and health (NIOSH). Decision Logic for Work-Related Asthma [Internet]. Atlanta (GA): Centers for disease control and prevention, c2018 [cited 2018 Mar 1]. Available from: http://www.cdc. gov/niosh/topics/surveillance/ords/statebasedsurveillance/ re-portingguidelines-wra.html\# WRAGuidelines.

49. Mapp CE, Boschetto P, Maestrelli P, Fabbri LM. Occupational asthma. Am J Respir Crit Care Med 2005;172:280-305.

50. Agusti A, Bel E, Thomas M, et al. Treatable traits: toward precision medicine of chronic airway diseases. Eur Respir J 2016;47:410-419.

51. Wenzel S. Severe asthma in adults. Am J Respir Crit Care Med 2005;172:149-160.

52. Pakhale S, Mulpuru S, Boyd M. Optimal management of severe/refractory asthma. Clin Med Insights Circ Respir Pulm Med 2011;5:37-47.

53. Ayres JG, Bateman ED, Lundbäck B, Harris TA. High dose fluticasone propionate, $1 \mathrm{mg}$ daily, versus fluticasone propionate, $2 \mathrm{mg}$ daily, or budesonide, $1.6 \mathrm{mg}$ daily, in patients with chronic severe asthma. International Study Group. Eur Respir J 1995;8:579-586.

54. Pauwels RA, Löfdahl CG, Postma DS, et al. Effect of inhaled formoterol and budesonide on exacerbations of asthma. formoterol and corticosteroids establishing therapy (FACET) international study group. $\mathrm{N}$ Engl J Med 1997;337:1405-1411.

55. Aaronson D, Kaiser H, Dockhorn R, et al. Effects of budesonide by means of the turbuhaler on the hypothalmic-pituitary-adrenal axis in asthmatic subjects: a dose-response study. J Allergy Clin Immunol 1998;101:312-319.

56. Reddel HK, Jenkins CR, Marks GB, et al. Optimal asthma control, starting with high doses of inhaled budesonide. Eur Respir J 2000;16:226-235.

57. Skinner C. Comparison of oral prednisolone and intra- muscular depot triamcinolone in patients with severe chronic asthma. Thorax 1984;39:880.

58. Ogirala RG, Aldrich TK, Prezant DJ, Sinnett MJ, Enden JB, Williams MH Jr. High-dose intramuscular triamcinolone in severe, chronic, life-threatening asthma. N Engl J Med 1991;324:585-589.

59. ten Brinke A, Zwinderman AH, Sterk PJ, Rabe KF, Bel EH. "Refractory" eosinophilic airway inflammation in severe asthma: effect of parenteral corticosteroids. Am J Respir Crit Care Med 2004;170:601-605.

60. Corrigan CJ, Loke TK. Clinical and molecular aspects of glucocorticoid resistant asthma. Ther Clin Risk Manag 2007;3:771-787.

61. Barnes PJ. Glucocorticosteroids: current and future directions. Br J Pharmacol 2011;163:29-43.

62. Adcock M. Mechanisms and clinical implications of glucocorticoid resistance in asthma [Internet]. Boston (MA): UpToDate, c2018 [cited 2018 Mar 1]. Available from: https://www.uptodate.com/contents/ mechanisms-and-clinical-implications-of-glucocorticoid-resistance-in-asthma?cs $=848 \mathrm{efdd} 4-641 \mathrm{c}-4 \mathrm{fa} 3-\mathrm{a} 2 \mathrm{e} 5-\mathrm{e} 66 \mathrm{dfc} 945 \mathrm{a} 8 \mathrm{a} \&$ source=contentShare.

63. Woodruff PG, Modrek B, Choy DF, et al. T-helper type 2-driven inflammation defines major subphenotypes of asthma. Am J Respir Crit Care Med 2009;180:388-395.

64. Hanania NA, Wenzel S, Rosen K, et al. Exploring the effects of omalizumab in allergic asthma: an analysis of biomarkers in the EXTRA study. Am J Respir Crit Care Med 2013;187: 804-811.

65. Wenzel S. Treatment of severe asthma in adolescents and adults, 2018 UpToDate [Internet]. Boston (MA): UpToDate, c2018 [cited 2018 Mar 1]. Available from: https://www. uptodate.com/contents/treatment-of-severe- asthma-in-adolescents-and-adults? csi=8e 1 a 0 ba $4-694$ a-474388a8-d7617b4aef3f \&source=contentShare.

66. Bousquet J, Siergiejko Z, Swiebocka E, et al. Persistency of response to omalizumab therapy in severe allergic (IgEmediated) asthma. Allergy 2011;66:671-678.

67. Hur GY, Kim TB, Kim ST, et al. Allergy Immunotherapy. Korean J Asthma Allergy Clin Immunol 2010;30:153-183.

68. Virchow JC, Backer V, Kuna P, et al. Efficacy of a house dust mite sublingual allergen immunotherapy tablet in adults with allergic asthma: a randomized clinical trial. JAMA 2016;315:1715-1725.

69. Silva CI, Colby TV, Müller NL. Asthma and associated conditions: high-resolution $\mathrm{CT}$ and pathologic findings. AJR Am J Roentgenol 2004;183:817-824.

70. Donohue KM, Hoffman EA, Baumhauer H, et al. Asthma and lung structure on computed tomography: the multi-ethnic study of atherosclerosis lung study. J Allergy Clin Immunol 2013;131:361-368.e1-e11. 
71. Kim HG, Lee HK, Kweon BC, et al. Two cases of upper airway obstruction masquerading as asthma: one tracheal adenoid cystic carcinoma, the other foreign body aspiration. $\mathrm{J}$ Asthma Allergy Clin Immunol 1999;19:103-109.

72. Global Initiative for Chronic Obstructive Lung Disease. GOLD 2017 Global Strategy for the Diagnosis, Management and Prevention of COPD [Internet]. Fontana (WI): Global Initiative for Chronic Obstructive Lung Disease, c2018 [cited 2018 Mar 1]. Available from:http:/goldcopd. org/ gold-2017-global-strategy-diagnosis-management-prevention -copd/. 